\title{
USING OF LED LIGHTING IN POULTRY PREMISES
}

\author{
T. Knyzhka, Candidate of Technical Sciences, Senior Lecturer \\ O. Romanenko, Candidate of Technical Sciences, Senior Lecturer \\ National University of Life and Environmental Sciences of Ukraine
}

E-mail:knizhkatetiana@mail.ru

\begin{abstract}
The article discusses the advantages and the feasibility of using luminescent and LED light sources to create effective light modes in poultry houses to obtain the highest possible performance. The influence of the spectral composition of light sources on the productive qualities of poultry is investigated.

It is known that optical radiation has a significant impact on the bird's body: gas exchange, the activity of the blood-forming organs, the biochemical composition of the blood, the work of the endocrine glands, including the sex glands. It can stimulate or, on the contrary, inhibit the development of the sex glands and their activity. The duration of daylight has the greatest influence. Therefore, additional lighting is widely used to stimulate bird productivity.

The light energy perceived by the retina is transformed into nerve impulses that, stimulating the corresponding nerve centers, increase the vitality of the body, namely metabolism, thus stimulating the overall physiological and reproductive function of the bird.

One of the important elements of poultry keeping technology is the livestock lighting programs. In this case, they have a great significance, such as the duration of photoperiods, the level of illumination, and the spectrum of light.

It is established that fluorescent lamps and LED lighting contributes to the most rapid achievement of $50 \%$ and $75 \%$ of egg production, as well as the peak of egg production, which occurs 9 and 12 days earlier than with incandescent lighting. The use of fluorescent and LED lamps leads to an increase in the intensity of egg production of laying hens by $3.1 \%$ and $6.6 \%$, which confirms the greater promise of using LED lamps above fluorescent ones to illuminate premises for laying hens.
\end{abstract}

Key words: efficiency, performance, LED lamps, lighting modes, poultry keeping technology, egg production

Introduction. It is known that optical radiation has a significant impact on the bird's body: gas exchange, the activity of the blood-forming organs, the biochemical composition of the blood, the work of the endocrine glands, including the sex glands. It can stimulate or, on the contrary, inhibit the development of the sex glands and their 
activity. The duration of daylight has the greatest influence. Therefore, additional lighting is widely used to stimulate bird productivity [1].

Analysis of recent researches and publications. The study of the effects of optical radiation on the physiological state and productivity of poultry is devoted to the study of many scientists, among them V.F. Larionov, S. Fox, D. King.

It has been proved that optical radiation in the body of the bird causes profound physiological changes, especially in the endocrine and generative systems. The light energy perceived by the retina is transformed into nerve impulses that, stimulating the corresponding nerve centers, increase the vitality of the body, namely metabolism, thus stimulating the overall physiological and reproductive function of the bird [2].

Purpose - to investigate the influence of the spectral composition of light sources on productive poultry quality.

Methods. In the process of research, methods of photometry, mathematical modeling and system analysis were used.

Results. One of the important elements of poultry keeping technology is the livestock lighting programs. In this case, they have a great significance, such as the duration of photoperiods, the level of illumination, and the spectrum of light. [3-5].

The Department of Electrical Engineering, Electromechanics and Electrotechnology of NULES of Ukraine conducted research and analyzed the spectral characteristics of modern lamps, which are used for illumination of laying hens. These are OSRAM DULUX S 9W/830, OSRAM DULUX S/E 11W/840, and OVOSTAR M/N: PV-4ft-14W LED Tube and LedLife LFPL 600-22,5 [3]. The spectral characteristics of the luminescent (Fig. 1) and LED (Fig. 2) lamps are shown below.

In production conditions, the influence of the spectral composition of lamps on Egg Legs bird's egg production line was investigated, which was maintained in 3-level cell batteries in three sections. 
"Енергетика і автоматика", №1, 2019 р.

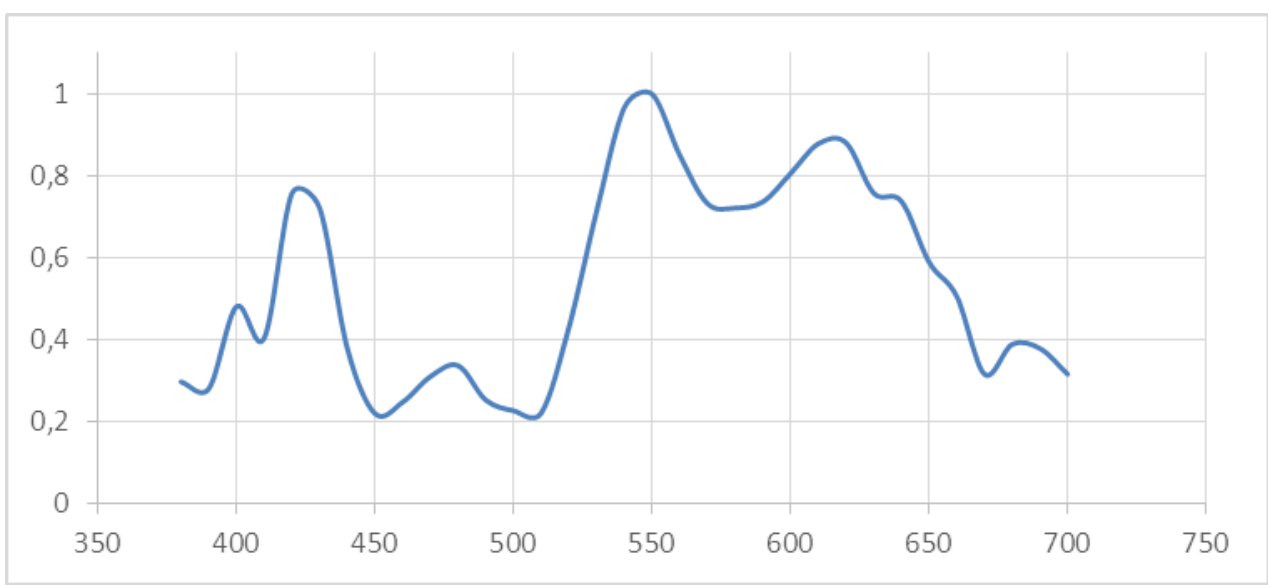

a)

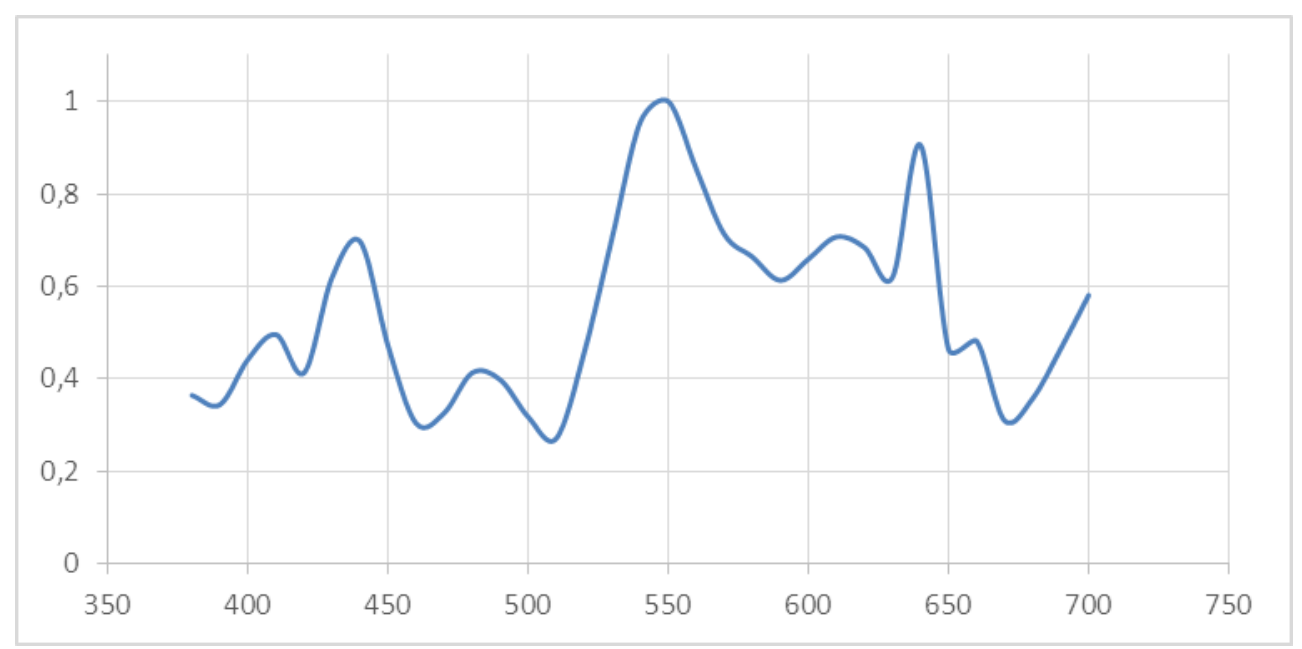

b)

Fig. 1. Spectral characteristic of a fluorescent lamp OSRAM DULUX S 9W/830 (a); OSRAM DULUX S/E 11W/840 (b)

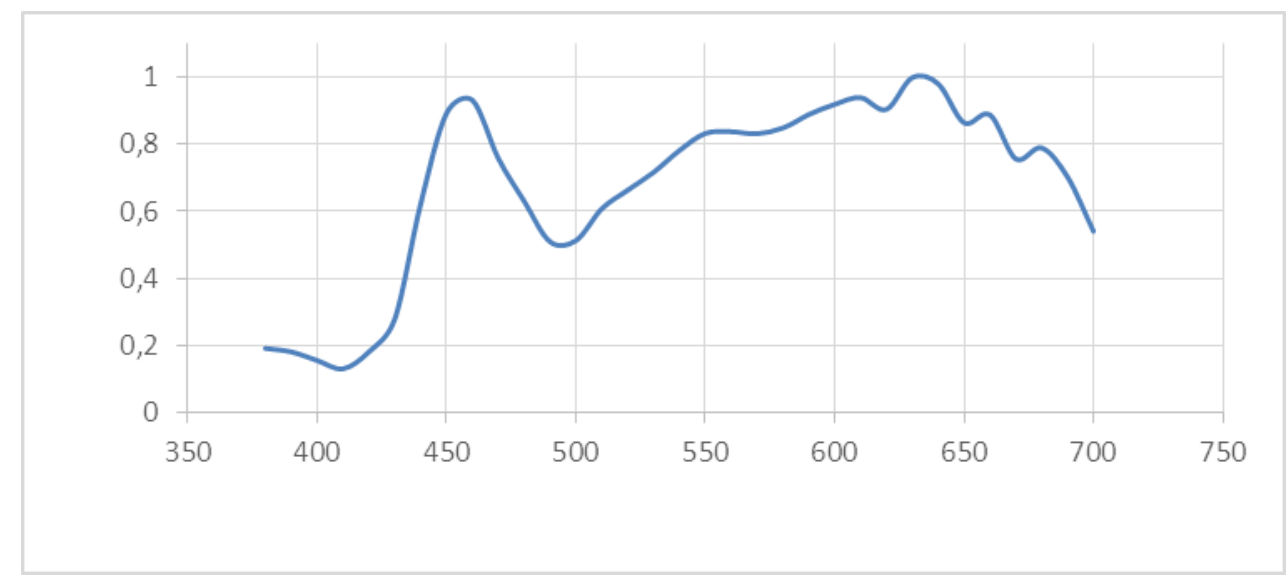

a) 


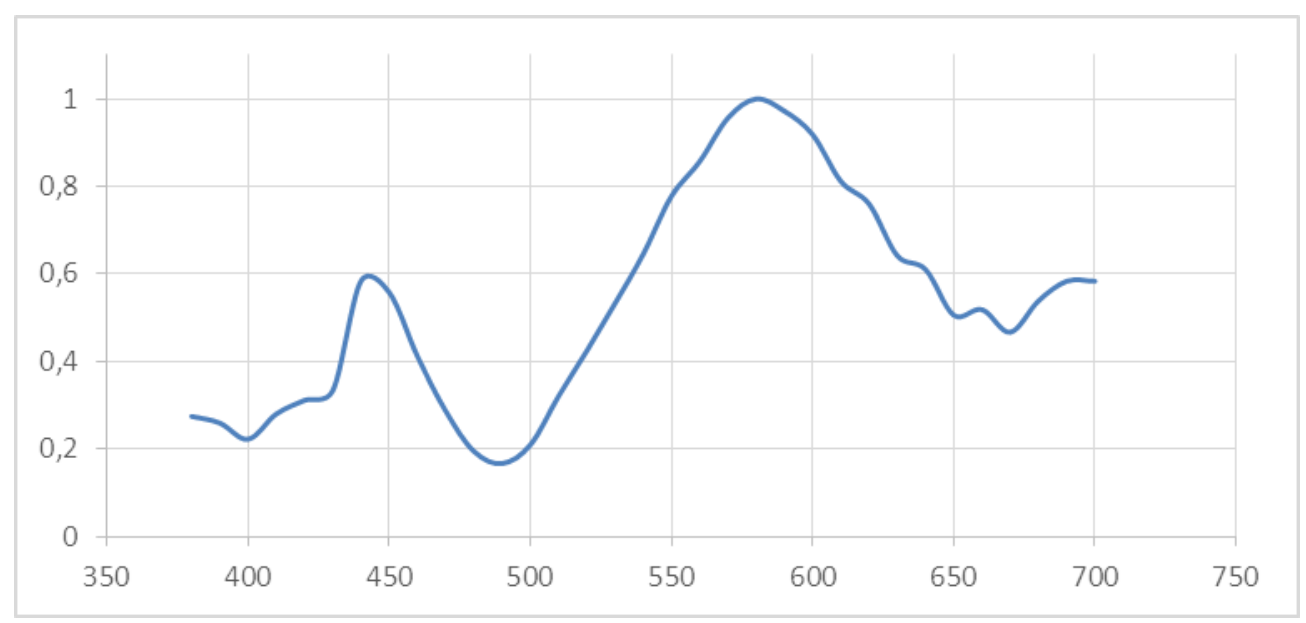

b)

Fig. 2. Spectral characteristic of LED lamps OVOSTAR M/N: PV-4ft-14W LED Tube (a); LedLife LFPL 600-22,5 (b)

The research was conducted in three groups. In order to preserve the given light regime in the 1st group, incandescent lamps were used, in the 2nd - fluorescent lamps, in the 3rd - LED lamps. The duration of light day and the intensity of irradiation on the working surface were the same. The studies were conducted within three months. The results of the studies are presented in the table.

The feeding of experimental birds was carried out with full feed fodder. Multiplicity of feeding hens-bearers - twice a day. Napping - with nipple drinking. Formula lighting mode: 14 hours. light 10 hours. darkness. The presence of chickens-bearers was evaluated on the basis of the initial and middle bearings, on the basis of the fertility intensity of each month of the oviposition and over the entire period of the experiment. Record keeping was carried out on a daily basis in the number of demolished eggs by each group of laying hens.

According to the results of the experiment, it can be stated that the age of the bird prior to the appearance of the first egg and the achievement of 5\% of the carcass in all groups of chickens was practically the same (deviation within the experimental error). 25 $\%$ productivity was obtained from chickens of the second experimental group, where fluorescent lamps were used. The LED lamps used in the third experimental group of 
laying hens caused the fastest achievement of $50 \%$ and $75 \%$ of the carrier, as well as the peak of the carrier, which occurred 12 days before the control group when illuminated by incandescent lamps.

\section{Productivity of hens-bearers}

\begin{tabular}{|c|c|c|c|}
\hline \multirow{2}{*}{ Index } & \multicolumn{3}{|c|}{ Groups } \\
\cline { 2 - 4 } & control & experimental ones \\
\cline { 2 - 4 } & 1 & 2 & 3 \\
\hline Demolition of the first egg, \% & 140 & 144 & 142 \\
5 & 147 & 147 & 146 \\
\hline 25 & 156 & 155 & 153 \\
\hline 50 & 169 & 164 & 160 \\
\hline 75 & 220 & 211 & 208 \\
\hline Age of reaching the peak of weight, days & 163,2 & 168,3 & 174 \\
\hline Insecurity during the experiment, pc & & & \\
\hline
\end{tabular}

Indicators of carcass during the experiment of hens of the 2nd and 3rd experimental groups prevailed in control by $3.1 \%$ and $6.6 \%$ respectively.

It should be noted that LED lighting including modern LED equipment can be freely used in all conditions; to ensure the safety of people and the environment - the LED product does not contain inert gas, mercury and does not emit harmful ultraviolet radiation.

Discussion. Studies have shown that fluorescent lamps and, in particular, LED lighting contributes to the fastest reach of $50 \%$ and $75 \%$ of bearing, as well as the bursting peak, which was applied 9 and 12 days earlier than when lit by incandescent lamps. It has been established that the use of fluorescent lamps and LED lamps causes an increase in the carrying capacity of chickens for laying hens at $3.1 \%$ and $6.6 \%$, which confirms the promise of using LED lamps above fluorescent for lighting the premises for keeping bear chickens.

\section{References}

1. Halliamova, T. R., Shyrobokova, T. A., Shuvalova, L. A. (2014) Vlyianye razlychnыkh ystochnykov sveta na produktyvnost kur [The effect of various light sources on the productivity of chickens] Sovremennye problemy nauky y obrazovanyia, 6 .

2. Solovei, O. I., Cherniavsky, A. V., Hryshchuk, Iu. O. (2014) Vybir optymalnoho dzherela svitla dlia tekhnolohichnoho osvitlennia ptashnyka [Choosing the optimal light 
source for technological lighting of the poultry house] Svitlotekhnika ta elektroenerhetyka, $2,28-32$.

3. Chervinskyi, L. S. Knyzhka, T. S., Romanenko, O. I. (2017) Obhruntuvannia zastosuvannia svitlodiodnoho osvitlennia $\mathrm{v}$ ptakhivnychykh prymischenniakh [Justification of the use of LED lighting in poultry houses] Enerhetyka i avtomatyka, 4.

4. Chervinskyi, L. S. Knyzhka, T. S., Romanenko, O. I. (2013) Vplyv elektromahnitnykh poliv na zhyvi orhanizmy i mekhanizmy yikh vplyvu [Influence of electromagnetic fields on living organisms and mechanisms of their influence] Visnyk Kharkivskoho natsionalnoho tekhnichnoho universytetu silskoho hospodarstva imeni Petra Vasylenka, 142, 116-119.

5. Chervinskyi, L. S., Knyzhka, T. S., Romanenko, O. I., Lutsak, Ia. M. (2016) Teoretychne obhruntuvannia mekhanizmu keruvannia vplyvom optychnoho vyprominiuvannia na biolohichni systemy na osnovi fotoreaktyvatsii [Theoretical substantiation of the mechanism of control of the influence of optical radiation on biological systems on the basis of photoreactivation] Naukovyi visnyk NUBiP Ukrainy, 242, 106-116.

\section{ЗАСТОСУВАННЯ СВІТЛОДІОДНОГО ОСВІТЛЕННЯ У ПТАХІВНИЧИХ ПРИМШЩЕННЯХ \\ Т. С. Книжка, О. І. Романенко}

Анотація. Розглядаються переваги та доиільність використання люмінесцентних та світлодіодних джерел світла для створення ефективних режимів освітлення в пташниках з метою досягнення максимально можливої продуктивності. Досліджено вилив спектрального складу джерел світла на продуктивні якості птичі.

Відомо, щео оптичне випромінювання має суттєвий вплив на організм птиці: газообмін, діяльність кровотворних органів, біохімічний склад крові, робота залоз внутрішньої секреції, в тому числі статевих залоз. Оптичне випромінювання може стимулювати або, навпаки, перешкоджати розвитку статевих залоз $i$ ïх активності. Тривалість денного світла має найбільший вплив. Тому додаткове освітлення широко використовується для стимулювання продуктивності птахів.

Світлова енергія, що сприймається сітківкою, перетворюється в нервові імпульси, які, стимулюючи відповідні нервові центри, підвищують життездатність організму, а саме обмін речовин, стимулюючи тим самим загальну фізіологічну і репродуктивну функиію птиці.

Одним з важливих елементів технології утримання птиці $\epsilon$ програми освітлення: тривалість фотоперіодів, рівень освітленості і спектр світла.

Досліджено вплив спектрального складу джерел світла на продуктивні якості птиці. Встановлено, що люмінесиентні лампи $і$ світлодіодне освітлення сприяє якнайшвидшому досягненню $50 \%$ i $75 \%$ несучості, а також піку несучості, який настає на 9 i 12 діб раніше, ніж при освітленні лампами розжарювання. Використання люмінесцентних та світлодіодних ламп призводить до підвищення інтенсивності несучості курей-несучок на 3,1 \% і 6,6 \%, що підтверджує велику 
"Енергетика і автоматика", №1, 2019 р.

перспективність використання світлодіодних ламп над люмінесцентними для освітлення приміщуень для утримання курей-несучок.

Ключові слова: ефективність, продуктивність, світлодіодні лампи, режими освітлення, технологія птахівнццтва, виробництво яєць ПРИМЕНЕНИЕ СВЕТОДИОДНОГО ОСВЕЩЕНИЯ В ПТИЦЕВОДЧЕСКИХ ПОМЕЩЕНИЯХ

\section{Т. С. Книюкка, А. И. Романенко}

Аннотация. Рассматриваются преимущуества и цуелесообразность использования люминесиентных и светодиодных источников света для создания эффективных режимов освещуения в птичниках с изелью достижения максимально возможной производительности. Исследовано влияние спектрального состава источников света на продуктивные качества птицы.

Известно, что оптическое излучение оказывает сущуественное влияние на организм птицы: газообмен, деятельность кроветворных органов, биохимический состав крови, работа желез внутренней секреции, в том числе половых желез. Оптическое излучение может стимулировать или, наоборот, препятствовать развитию половых желез и их активности. Продолжительность дневного света имеет наибольшее влияние. Поэтому дополнительное освещуение иироко используется для стимулирования продуктивности птиц.

Световая энергия, воспринимаемая сетчаткой, преобразуется в нервные импульсы, которые, стимулируя соответствуюшие нервные центры, повышают жизнеспособность организма, а именно обмен веществ, стимулируя тем самым общую физиологическую и репродуктивную функиию птиць.

Одним из важных элементов технологии содержания птиць являются программы освещуения: продолжительность фотопериодов, уровень освещенности и спектр света.

Исследовано влияние спектрального состава источников света на продуктивные качества птицьы. Установлено, что люминесцентные лампь и светодиодное освещуение способствует наиболее быстрому достижению $50 \%$ и 75 \% яйценоскости, а также пике яйценоскости, который наступает на 9 и 12 суток раньще, чем при освещении лампами накаливания. Использование люминесцентных и светодиодных ламп приводит к повышению интенсивности яйценоскости курнесушек на 3,1 \% и 6,6 \%, что подтверждает большую перспективность использования светодиодных ламп над люминесцентными для освещееня помещуений для содержания кур-несушек.

Ключевые слова: эффективность, производительность, светодиодные лампы, режимы освещения, технология птицеводства, производство яиц 